\title{
Relation between respiratory symptoms, type of farming, and lung function disorders in farmers
}

\author{
Martin Iversen, Bente Pedersen
}

\begin{abstract}
Respiratory symptoms and function were examined in a random sample of 181 farmers (124 pig farmers and 57 dairy farmers) with a mean age of 43 years. Wheezing and shortness of breath during work in the animal house were significantly associated with pig farming (odds ratio 11.4), current smoking (odds ratio $2 \cdot 2$ ), bronchial hyperreactivity (odds ratio 3.8), and low $\mathrm{FEV}_{1}$ (odds ratio 3.4). Pig farmers had a slightly lower FEV 1 than dairy farmers $(101 \%$ versus $104 \%$ predicted, NS). Symptomatic farmers had significantly lower FEV $_{1}$ than symptomless farmers $(93 \%$ versus $106 \%$ predicted). A multiple linear regression analysis of the cross sectional values of FEV 1 showed that there was a decline in FEV $_{1}$ associated with pig farming ( $-12 \mathrm{ml} /$ year of pig farming) and smoking $(-23 \mathrm{ml} / \mathrm{pack}$ year $)$ in addition to the age related decline of $32 \mathrm{ml} /$ year. A multiple linear regression analysis of $\mathbf{P C}_{20}$ histamine showed that bronchial reactivity increased with age, number of pack years, and number of years in pig farming. Work in closed pig rearing units is a pulmonary health hazard and causes decline in lung function.
\end{abstract}

Farmers have a high prevalence of respiratory symptoms ${ }^{1-3}$ and airways obstruction..$^{23}$ Pig farming appears to be a special risk factor for the development of respiratory symptoms ${ }^{47}$ and a high percentage of farmers with asthma and respiratory symptoms have severe airways obstruction irrespective of the type of farming. ${ }^{8}$ In our previous study the group of farmers was obtained by stratified sampling. The aim in this study was to study these relations in more detail in a well defined group of farmers obtained by random sampling.

\section{Methods}

STUDY POPULATION

Department of Respiratory Diseases, University Hospital Aarhus, Denmark Marhus, Dersen

B Pedersen

Address for reprint requests: $M$ Iversen, Lungeklinikken, Aarhus Kommunehospital, 8000 Aarhus C, Denmark

Accepted 13 August 1990 intended to be a random sample of farmers with large modern farms who are likely to be in farming for many years. Their personal characteristics are given in table 1. A letter
The Farmers Association in three palities was asked to supply a list of all pig and dairy farmers with medium sized and large explaining the purpose of the study and asking the farmers to participate was sent to 175 randomly selected farmers. Two refused to participate and seven were excluded because of various diseases (recent treatment for cancer 2, recent myocardial infarction 2, Parkinson's disease 1, sarcoidosis 2). Five farmers had been misclassified (they combined pig and dairy farming) and were thus not eligible for study. Three symptomless farmers were excluded because they could not perform lung function tests in a reproducible manner. They appeared to have normal lung function. In addition to the 158 farmers recruited through the Farmers Association, 29 pig farmers volunteered for lung function tests and fibreoptic bronchoscopy with lavage. There was no significant difference between the four groups of pig farmers (three districts and one volunteer group) with respect to age (up to and over 40 years), smoking, and frequency of respiratory symptoms during work $\left(\chi^{2}\right.$ test, $\mathrm{p}>0.05)$. Six farmers were female and were not included in the study. Thus the total study population consisted of 181 farmers, of whom 124 were pig farmers and 57 dairy farmers.

\section{QUESTIONNAIRE}

All farmers had a structured interview with questions on respiratory symptoms, working conditions, smoking habits, and family history and standardised questions on chronic bronchitis (Medical Research Council criteria). Special emphasis was given to respiratory symptoms during work that suggested airways narrowing or irritation (shortness of breath, wheezing, and dry cough).

\section{LUNG FUNCTION TESTS}

Lung function was measured with the Jaeger Transferscreen II (Eric Jaeger GMBH, Würzburg, Germany). A nose clip was used during all measurements. Inspiratory vital capacity (VC), single breath transfer factor for carbon monoxide (TLCO), TLCO per litre alveolar volume (TLCO/VA), residual volume (RV), and functional residual capacity (FRC) were measured with the subject seated. The forced expiratory volume in one second $\left(\mathrm{FEV}_{1}\right)$ and forced vital capacity (FVC) were measured with the subject standing. Tests were performed according to accepted guidelines ${ }^{9}$; the predicted values were the European values of Quanjer et al. ${ }^{9}$ Histamine challenge was performed by the method of Cockcroft et al..$^{10} \mathrm{~A}$ Wright's nebuliser calibrated to an output of $0.13-0.14 \mathrm{ml} / \mathrm{min}$ was used with 
Table 1 Characteristics of the 181 farmers

\begin{tabular}{|c|c|c|c|}
\hline & $\begin{array}{l}\text { Pig farmers } \\
(n=124)\end{array}$ & $\begin{array}{l}\text { Dairy farmers } \\
(n=57)\end{array}$ & $p$ \\
\hline Mean age (y) & $42 \cdot 8$ & $43 \cdot 4$ & 0.75 \\
\hline $\begin{array}{l}\text { \% with work related symptoms } \\
\text { Shortness of breath } \\
\text { Wheezing } \\
\text { Dry cough } \\
\text { Any symptom }\end{array}$ & $\begin{array}{l}30 \\
21 \\
32 \\
39\end{array}$ & $\begin{array}{l}6 \\
2 \\
4 \\
5\end{array}$ & $\begin{array}{l}<0.01 \\
<0.01 \\
<0.01 \\
<0.01\end{array}$ \\
\hline $\begin{array}{l}\% \text { with aggravation of respiratory sympto } \\
\text { by: } \\
\text { Physical exercise } \\
\text { Cold air } \\
\text { Tobacco smoke } \\
\text { Coryza }\end{array}$ & $\begin{array}{l}18 \\
13 \\
19 \\
22\end{array}$ & $\begin{array}{r}7 \\
0 \\
4 \\
11\end{array}$ & $\begin{array}{l}0.08 \\
0.01 \\
0.01 \\
0.08\end{array}$ \\
\hline $\begin{array}{l}\% \text { who were current smokers } \\
\% \text { with chronic bronchitis } \\
\% \text { with } \mathrm{PC}_{20} \text { histamine } \leqslant 32 \mathrm{mg} / \mathrm{ml} \\
\text { Mean FEV } \% \text { predicted } \\
\text { Geometric mean } \mathrm{PC}_{20} \text { histamine }(\mathrm{mg} / \mathrm{ml})\end{array}$ & $\begin{array}{c}20 \\
24 \\
50 \\
101 \\
11 \cdot 7\end{array}$ & $\begin{array}{c}33 \\
19 \\
42 \\
104 \\
16 \cdot 8\end{array}$ & $\begin{array}{l}0 \cdot 19 \\
0 \cdot 46 \\
0 \cdot 36 \\
0 \cdot 36 \\
0 \cdot 11\end{array}$ \\
\hline
\end{tabular}

^Symptoms suggesting upper respiratory tract infection.

$2 \mathrm{ml}$ of test solution in the nebuliser. For the inhalation the subject performed two minutes' tidal breathing wearing a nose clip. FEV $_{1}$ was measured 30 and 90 seconds after each inhalation (Vitalograph S-26000, Buckingham). The test started with inhalation of isotonic saline and the $\mathrm{FEV}_{1} 90$ seconds later was used as the baseline value in further calculations. Histamine chloride was then inhaled in increasing concentrations until a maximum concentration of $32 \mathrm{mg} / \mathrm{ml}$ had been reached or the $\mathrm{FEV}_{1}$ had fallen more than $20 \%$ from baseline. Challenge in symptomless subjects was usually performed with 2,8 and $32 \mathrm{mg} / \mathrm{ml}$ histamine, whereas in subjects with asthma or severe symptoms of wheezing the first concentration used was $0.03 \mathrm{mg} / \mathrm{ml}$ histamine. The provocative concentration of histamine causing a $20 \%$ fall in $\mathrm{FEV}_{1}\left(\mathrm{PC}_{20}\right.$ histamine) was determined by linear interpolation on a logarithmic concentration-response plot between the concentration that caused a greater than $20 \%$ fall in $\mathrm{FEV}_{1}$ and the preceding concentration. Bronchial hyperreactivity in this study means a $\mathrm{PC}_{20}$ histamine of $32 \mathrm{mg} /$ $\mathrm{ml}$ or less. When $\mathrm{PC}_{20}$ was over $32 \mathrm{mg} / \mathrm{ml} \mathrm{a}$ value of $33 \mathrm{mg} / \mathrm{ml}$ was assigned. $\mathrm{PC}_{20}$ values were log transformed for analysis.

ANALYSIS

Statistical evaluation was performed with the Statistical Package for the Social Sciences (SPSS). ${ }^{11}$ Comparison of means for parametric values was done by analysis of variance. Association between discrete variables was examined by the $\chi^{2}$ test and the odds ratio $^{12}$ was used to indicate the degree of association between two dichotomous variables. Confidence limits for odds ratios were calculated according to the method of Miettinen, ${ }^{13}$ and this was also used to give an approximation for odds ratios from the Mantel-Haenszel test ${ }^{14}$ when this was used to examine dichotomous variables in stratified analysis. Multiple linear regression analysis was used to evaluate which factors influenced $\mathrm{FEV}_{1}$ and $\mathrm{PC}_{20}$. When no other values are given, the limit of significance is $5 \%$ and confidence limits are $95 \%$ limits. To avoid age and height bias for $\mathrm{FEV}_{1}$ and other lung function measurements the standardised deviations were used (that is, the observed value minus the predicted value divided by the residual standard variation ${ }^{915}$ ) and denoted by the prefix $S$ (for example, $S_{F E V}$ ).

\section{Results}

Personal characteristics

There was no significant difference between pig and dairy farmers in mean age (42.8 and 43.4 years), percentage of current smokers $(20 \%$ and $33 \%)$, percentage with Medical Research Council criteria of chronic bronchitis $(24 \%$ and $19 \%)$, and $\mathrm{FEV}_{1}$ as a percentage of the predicted value $(101 \%$ and $104 \%)$. Geometric mean $\mathrm{PC}_{20}$ histamine did not differ significantly between pig farmers $(11.7 \mathrm{mg} / \mathrm{ml})$ and dairy farmers $(16.8 \mathrm{mg} / \mathrm{ml})$. The proportion of subjects with a $\mathrm{PC}_{20}$ histamine value below $32 \mathrm{mg} / \mathrm{ml}$ was higher in pig farmers (62, $50 \%)$ than in dairy farmers $(24,42 \%)$ but this difference was not significant. A pronounced difference between groups was found for the symptoms shortness of breath, wheezing, and dry cough during work; one or more of these symptoms occurred in $48(39 \%)$ of the pig farmers and $3(5 \%)$ of the dairy farmers $(p<0.01)$. Pig farmers had significantly more exacerbations of respiratory symptoms during exercise, when exposed to tobacco smoke or cold air, or during a coryzal illness than dairy farmers (table 1). All farmers had worked in farming since their youth. For pig farmers the median number of years exclusively in pig farming was 12 years and the median number of years with lung symptoms was five years.

When farmers were divided into those with shortness of breath, wheezing, or dry cough during work in the animal house and those without such symptoms the mean age did not differ, being $42 \cdot 2$ years in symptomless farmers and $45 \cdot 1$ years in symptomatic farmers (table 2). Symptomatic farmers included more smokers $(18,35 \%$ v 26, 20\%) and had a lower FEV $\%$ predicted $(93 \% v 106 \%)$ and a lower $\mathrm{PC}_{20}$ histamine $(5.6 \mathrm{mg} / \mathrm{ml} \quad v \quad 18.1 \mathrm{mg} / \mathrm{ml})$ than symptomless farmers; all these differences were significant $(\mathrm{p}<0.01)$.

\section{ASSOCIATION BETWEEN VARIABLES}

The reporting of any work related respiratory symptom (shortness of breath, wheezing, or dry cough) was significantly associated with current smoking (odds ratio $2 \cdot 2,95 \%$ confidence limits $1 \cdot 1-4 \cdot 4$ ), pig farming (odds ratio $11 \cdot 4,4 \cdot 1-31 \cdot 7), \mathrm{PC}_{20}$ histamine $\leqslant 32 \mathrm{mg} / \mathrm{ml}$ (odds ratio $3 \cdot 8,2 \cdot 0-7 \cdot 6$ ), and low $\mathrm{FEV}_{1}$ defined as an $\mathrm{SFEV}_{1}$ of less than -1 (odds ratio 3.4 , $1 \cdot 5-7 \cdot 7)$ but not with age $(\leqslant 40,>40$ years) (odds ratio 1.1, 0.9-1.2). Current smoking, low $\mathrm{FEV}_{1}$, and a $\mathrm{PC}_{20}$ histamine value of $32 \mathrm{mg} / \mathrm{ml}$ or less were all significantly associated with each other $(p<0.05)$.

Because of the interrelation between variables some of the associations between symptoms and pig farming, smoking, and bronchial 
Table 2 Characteristics of the 51 farmers with shortness of breath, wheezing, or dry cough during work in the animal house and of the 130 farmers without such symptoms

\begin{tabular}{|c|c|c|c|}
\hline & $\begin{array}{l}\text { No symptoms } \\
(n=130)\end{array}$ & $\begin{array}{l}\text { Symptoms } \\
(n=51)\end{array}$ & $p$ \\
\hline Mean age (years) & $42 \cdot 2$ & $45 \cdot 1$ & $0 \cdot 12$ \\
\hline$\%$ who were current smokers & 20 & 35 & $<0.01$ \\
\hline$\%$ with $\mathrm{PC}_{20}$ histamine $\leqslant 32 \mathrm{mg} / \mathrm{ml}$ & 39 & 71 & $<0.01$ \\
\hline$\%$ with SFEV $\star \star<-1$ & 10 & 28 & $<0.01$ \\
\hline Mean $\mathrm{FEV}_{1} \%$ predicted & 106 & 93 & $<0.01$ \\
\hline Mean FVC $\%$ predicted & 105 & 95 & $<0.01$ \\
\hline Geometric mean $\mathrm{PC}_{20}$ histamine $(\mathrm{mg} / \mathrm{ml})$ & $18 \cdot 1$ & $5 \cdot 6$ & $<0.01$ \\
\hline
\end{tabular}

${ }^{\star} \mathrm{SFEV}_{1}$ is the standardised deviation of $\mathrm{FEV}_{1}$.

hyperreactivity were analysed with stratification for relevant variables. The strong association between pig farming and respiratory symptoms during work was even stronger after stratification for smoking (odds ratio 16.5, 5.549.2). The association between respiratory symptoms during work and smoking (odds ratio $2 \cdot 2$ ) was stronger after stratification for pig versus dairy farming (odds ratio $3.8,2.0$ $7 \cdot 5)$. The association between respiratory symptoms during work and a $\mathrm{PC}_{20}$ histamine value of $32 \mathrm{mg} / \mathrm{ml}$ or less (odds ratio 3.8) was unchanged after stratification for pig versus dairy farming (odds ratio $4 \cdot 0,2 \cdot 0-8 \cdot 3$ ), but the number of dairy farmers with respiratory symptoms during work was small. The stratified analysis showed that pig farming, current smoking, and a $\mathrm{PC}_{20}$ value of $32 \mathrm{mg} / \mathrm{ml}$ or less were independent risk factors for shortness of breath, wheezing, or dry cough during work in the animal house.

\section{LUNG FUNCTION MEASUREMENTS}

Mean values of $\mathrm{FEV}_{1}, \mathrm{FVC}$, and VC were significantly higher than predicted values in dairy farmers, whereas this was only true for $\mathrm{VC}$ in pig farmers. The standardised deviations of lung function measurements were slightly lower in pig farmers than in dairy farmers but not significantly so (table 3 ). There was no significant difference between pig farmers and dairy farmers for TLCO $(13.2$ and $15.5 \mathrm{mmol}$ $\left.\mathrm{min}^{-1} \mathrm{kPa}^{-1}\right)$ and TLCo/VA $(1.8$ and $1.7 \mathrm{mmol}$ $\left.\min ^{-1} \mathrm{kPa}^{-1} 1^{-1}\right)$. Farmers with shortness of breath, wheezing, or dry cough had significantly lower values for FEV, FVC, and VC

Table 3 Lung function measurements in pig farmers and dairy farmers (means of observed (predicted) values and $95 \%$ confidence intervals (CI) for observed means)

\begin{tabular}{|c|c|c|c|}
\hline & $\begin{array}{l}\text { Pig farmers } \\
(n=124)\end{array}$ & $\begin{array}{l}\text { Dairy farmers } \\
(n=57)\end{array}$ & $p$ \\
\hline $\begin{array}{c}\mathrm{FEV}_{1}(1) \\
95 \% \mathrm{CI} \\
\mathrm{SR}^{\star}\end{array}$ & $\begin{array}{l}3 \cdot 98(3.98) \\
3 \cdot 82-4 \cdot 15 \\
0 \cdot 12\end{array}$ & $\begin{array}{l}3.89(3.71) \\
3.64-4.15 \\
0.35\end{array}$ & 0.29 \\
\hline $\begin{array}{l}\text { FVC (1) } \\
95 \% \mathrm{CI} \\
\mathrm{SR}^{\star}\end{array}$ & $\begin{array}{l}4 \cdot 85(4 \cdot 79) \\
4 \cdot 68-5 \cdot 01 \\
0 \cdot 10\end{array}$ & $\begin{array}{l}4 \cdot 76(4 \cdot 53) \\
4 \cdot 52-5 \cdot 00 \\
0 \cdot 38\end{array}$ & $0 \cdot 10$ \\
\hline $\begin{array}{l}\mathrm{VC}(\mathrm{l}) \\
95 \% \mathrm{CI} \\
\mathrm{SR}^{\star}\end{array}$ & $\begin{array}{l}5 \cdot 31(5 \cdot 00) \\
5 \cdot 15-5 \cdot 47 \\
0 \cdot 55\end{array}$ & $\begin{array}{l}5 \cdot 25(4 \cdot 72) \\
5.02-5 \cdot 48 \\
0.93\end{array}$ & 0.05 \\
\hline
\end{tabular}

*Mean standardised residual-that is, observed-predicted/residual standard deviation. than symptomless farmers, and this also applied to standardised values $(p<0.05)$. There was, however, no significant difference between symptomatic farmers and symptomless farmers with respect to TLCO (13.5 v $\left.14.5 \mathrm{mmol} \mathrm{min} \mathrm{m}^{-1} \mathrm{kPa}^{-1}\right)$, TLCo/VA (1.76 v 1.80

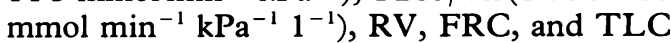
$(\mathrm{p}<0.05$ in each case). Thus pig farmers tended to have lower lung function measurements than dairy farmers but not significantly so; symptomatic farmers had evidence of airways narrowing with low $\mathrm{FEV}_{1}, \mathrm{FVC}$, and VC; but TLCo was preserved and there was no increase in RV.

VARIABLES ASSOCIATED WITH FEV

Multiple linear regression analysis was used to assess which factors influenced the cross sectional values of $F E V_{1}$ and $S F E V_{1}$. Height and age were included in the analysis of $\mathrm{FEV}_{1}$ but only age in the analysis of $S F E V_{1}$ to determine whether $\mathrm{SFEV}_{1}$ decreased with age-that is, whether the decrease in $\mathrm{FEV}_{1}$ with age was larger than expected from the regression equation for predicted values. Exposure variables were pack years for smoking and number of years spent exclusively in pig farming. The two regression models are shown in table 4. Height, age, number of pack years, and number of years in pig farming were all significantly associated with $\mathrm{FEV}_{1}$ and explained $58 \%$ of the variation in $\mathrm{FEV}_{1}$. Number of pack years and years of pig farming were significantly associated with $S_{F E V_{1}}$ whereas age was not. The yearly decrease of $\mathrm{FEV}_{1}$ estimated from the regression coefficients (model 1) was $32 \mathrm{ml} /$ year of age, $23 \mathrm{ml} /$ pack year, and $12 \mathrm{ml} /$ year of pig farming.

\section{ANALYSIS OF BRONCHIAL REACTIVITY}

Eighty seven $(48 \%)$ of the 181 farmers had a $\mathrm{PC}_{20}$ histamine value of $32 \mathrm{mg} / \mathrm{ml}$ or less and this was significantly associated with smoking, low $\mathrm{FEV}_{1}$, and older age $(\mathrm{p}<0.05)$. Multiple linear regression analysis using two regression models was performed with $\log \mathrm{PC}_{20}$ as the dependent variable (table 5). Age, years in pig farming, and number of pack years were all significantly associated with bronchial reactivity (model 1). With lung function $\left(\mathrm{SFEV}_{1}\right)$ included in the analysis (model 2) age and number of pack years were still significant predictors but not years in pig farming. $S_{F E V}$ was by far the most important factor associated with $\log \mathrm{PC}_{20}$ histamine.

\section{Discussion}

The study population was a random sample of a well defined group of farmers. With the criteria used the study population would for socioeconomic reasons consist of younger farmers with medium sized and large farms. This procedure was used instead of random sampling of all farmers as this would include a proportion of elderly farmers, part time farmers or farmers with small farms. Every year a large number of these farmers leave their farms. The results of this study confirm and extend the results of earlier studies. The high 
Table 4 Multiple regression analysis of $F E V_{1}$ and standardised deviation of $F E V_{1}$ $\left(S F E V_{1}\right)$ as dependent variables: unstandardised regression coefficients $(B)$ and their standard errors (SE) and significance of $B$

Model 1 : dependent variable FEV,

\begin{tabular}{lrlrl}
\hline Predictor variable & \multicolumn{1}{l}{$B$} & $S E$ of $B$ & \multicolumn{1}{l}{$p$} & \multicolumn{1}{c}{$R^{2 \star}$} \\
\hline Height (m) & 3.889 & 0.774 & $<0.001$ & 0.22 \\
Pig farming (y) & -0.012 & 0.006 & 0.036 & 0.29 \\
Smoking (pack y) & -0.023 & 0.004 & $<0.001$ & 0.49 \\
Age (y) & -0.033 & 0.005 & $<0.001$ & 0.58
\end{tabular}

$($ Constant $=-1 \cdot 189)$

Model 2: dependent variable SFEV,

\begin{tabular}{lllrl}
\hline Predictor variable & $B$ & $S E$ of $B$ & $p$ & $R^{2 \star}$ \\
\hline Age (y) & -0.005 & 0.009 & 0.567 & 0.09 \\
Pig farming (y) & -0.024 & 0.011 & 0.027 & 0.09 \\
Smoking (pack y) & -0.045 & 0.008 & $<0.001$ & 0.47 \\
(Constant =-1.046) & & & &
\end{tabular}

^Proportion of the variation in the dependent variable explained by successive steps in the regression equation.

Table 5 Multiple regression analysis of $\log P C_{20}\left(P C_{20}\right.$ in units of $0.01 \mathrm{mg} / \mathrm{ml}$ histamine ): unstandardised regression coefficients $(B)$ and their standard errors $(S E)$ and significance of $B$

Model 1 : dependent variable $\log P C_{20}$

\begin{tabular}{lllrl}
\hline Predictor variable & $B$ & $S E$ of $B$ & \multicolumn{1}{l}{$p$} & $R^{2 \star}$ \\
\hline Age (y) & -0.009 & 0.004 & 0.031 & 0.16 \\
Pig farming (y) & -0.014 & 0.005 & 0.007 & 0.18 \\
Smoking (pack y) & -0.020 & 0.004 & $<0.001$ & 0.30 \\
(Constant $=3.806)$ & & & &
\end{tabular}

Model 2: dependent variable log $P C_{20}$

\begin{tabular}{lrrrr}
\hline Predictor varaible & \multicolumn{1}{l}{ B } & SE of $B$ & \multicolumn{1}{c}{$p$} & \multicolumn{1}{c}{$R^{2 \star}$} \\
\hline Age (y) & -0.019 & 0.004 & 0.012 & 0.16 \\
SFEV & 0.236 & 0.031 & $<0.001$ & 0.44 \\
Pig farming (y) & -0.006 & 0.005 & 0.177 & 0.45 \\
Smoking (pack y) & -0.009 & 0.004 & 0.009 & 0.47 \\
(Constant 3.591) & & & &
\end{tabular}

^ Proportion of the variation in the dependent variable explained by the successive steps in the regression equation. association could only be seen in farmers with symptoms. Furthermore, the mean age of the farmers was high (58 years) and many had worked under conditions not representative of modern farming. The rate of decline in FEV (as assessed from the cross sectional data) due to age in this study ( $32 \mathrm{ml} /$ year) was very similar to the rate of decline indicated by the regression equation for the European predicted values $(29 \mathrm{ml} / \text { year })^{9}$ and similar to the age dependent decline ( $40 \mathrm{ml} / \mathrm{year}$ ) found in a study of 428 English farmers. ${ }^{17}$ The additional rate of decline associated with smoking $(23 \mathrm{ml} /$ pack year) was also close to that found in other studies. ${ }^{18}$ The additional rate of decline in $\mathrm{FEV}_{1}$ associated with pig farming $(12 \mathrm{ml} /$ year $)$ was similar to that found in a longitudinal study of 556 industrial workers, in whom dust exposure caused a $10-20 \mathrm{ml} /$ year decline in addition to the age and smoking related decline. ${ }^{19}$ In grain workers, whose exposure conditions may be more like those of farming than of industry, exposure to grain dust was associated with a decline in $\mathrm{FEV}_{1}$ similar to or somewhat smaller than that caused by smoking, and this effect seemed to be additive to that of smoking. ${ }^{20}$

Pig farmers ${ }^{21}$ and grain workers ${ }^{22}$ have a decline in $\mathrm{FEV}_{1}$ during a work shift and a six year follow up study ${ }^{23}$ showed that $10 \%$ of grain workers had an annual decline in $\mathrm{FEV}_{1}$ of over $100 \mathrm{ml} /$ year. This severe decline was associated with bronchial hyperreactivity and exposure to dust concentrations above $5 \mathrm{mg}$ / $\mathrm{m}^{3}$.

In this study $\mathrm{PC}_{20}$ histamine values of $32 \mathrm{mg} /$ $\mathrm{ml}$ and below defined bronchial hyperreactivity. This definition is arbitrary but the concentration of $32 \mathrm{mg} / \mathrm{ml}$ histamine represents the highest concentration that can be used with this method without intolerable side effects from histamine (hoarseness, cough, and flushing). Population studies ${ }^{24} 25$ have shown that only $10-20 \%$ of a random population sample have a $20 \%$ fall in $\mathrm{FEV}_{1}$ with acceptable doses of histamine and that the percentage of the population with a positive response to histamine challenge increases with age and smoking. The lowest prevalence of subjects with a positive response was found in non-smoking individuals aged 35-54 years. ${ }^{25}$ Given the mean age and the low prevalence of smoking, our study strongly suggests that farmers have increased levels of bronchial reactivity. The close association between bronchial hyperreactivity and respiratory symptoms has been found in population studies ${ }^{26}$ and in workers exposed to dust ${ }^{27}$ and the association of a positive response in the histamine test with older age and smoking agrees with the results from population studies. ${ }^{26}$ Bronchial reactivity was strongly influenced by $\mathrm{SFEV}_{1}$, and when correction was made for this age and pack years were significant predictors of $\log \mathrm{PC}_{20}$ whereas number of years in pig farming was not. Bronchial reactivity has been reported to be an independent predictor of decline in $\mathrm{FEV}_{1}{ }^{28}$ but because it was considered a response variable like $\mathrm{FEV}_{1}$ itself it was not included in the regression analysis of $\mathrm{FEV}_{1}$. ted as the most probable cause. ${ }^{616}$

In a cross sectional study ${ }^{8}$ pig farming was significantly associated with a low $\mathrm{FEV}_{1}$ but a stratified sampling technique was used and the 
The mean decline in $\mathrm{FEV}_{1}$ of $12 \mathrm{ml}$ per year of pig farming may seem low. Thirty years of exposure would amount to a decline of $360 \mathrm{ml}$, compared with an age related decline in $\mathrm{FEV}_{1}$ of about $1000 \mathrm{ml}$ in the same time. The crucial questions about these findings are whether they would be confirmed in a longitudinal study and whether some farmers will show a much steeper decline in $\mathrm{FEV}_{1}$ than most as a result of work in dusty pig rearing units. In a previous study only farmers with symptoms had evidence of impaired lung function. ${ }^{8} \mathrm{~A}$ group of symptomless farmers (mean age 52 years) still had a normal mean $\mathrm{FEV}_{1}$ and no one was below the lower $95 \%$ confidence limit for predicted values, whereas symptomatic farmers (mean age 58 years) had severe airways obstruction. This has implications for diagnosis and control of respiratory disease in farmers. Work in pig rearing units should be considered a pulmonary health hazard and some farmers will probably develop appreciable airways obstruction. Symptoms of chronic bronchitis and work related symptoms of shortness of breath, wheezing, and persistent dry cough should lead to clinical assessment and measurement of lung function so that airways obstruction is detected at an early stage.

This study was supported by Sygekassernes Helsefond, Copenhagen.

1 Husman K, Koskenvuo M, Kaprio J, Terho EO, Vohlonen I. Role of environment in the development of chronic bronchitis. Eur J Respir Dis 1987;71(suppl 152):57-63.

2 Saia B, Mastrangelo G, Marcer G, Reggio O. Prevalence and risk factors of chronic respiratory disease in a farming population. Med Lav 1984;75:101-9.

3 Dosman JA, Graham BL, Hall D, van Loon P, Bhasin P, Froh $F$. Respiratory symptoms and pulmonary function in farmers. J Occup Med 1987;29:39-43.

4 Donham KJ, Zavala DC, Merchant JA. Respiratory symptoms and lung function among workers in swine confinement buildings: a cross sectional study. Arch Environ Health 1984;39:96-100.

5 Donham KJ, Haglind P, Peterson Y, Rylander R. Environmental and health studies in swine confinement buildings. Am J Ind Med 1986;10:289-93.

6 Holness DL, O'Blenis EL, Saas-Kortsak A, Pilger C, Nethercott JR. Respiratory effects and dust exposure in hog confinement farming. Am J Ind Med 1987;11:571-80.

7 Iversen M, Dahl R, Korsgaard J, Hallas T, Jensen EJ. Respiratory symptoms in Danish farmers: an epidemiological study of risk factors. Thorax 1988;43:872-7.
8 Iversen M, Dahl R, Jensen EJ, Korsgaard J, Hallas T. Lung function and bronchial reactivity in farmers. Thorax 1989;44:645-9.

9 Quanjer Ph. Standardized lung function testing. Bull Eur Physiopathol Respir 1985;19(suppl 5):45-51.

10 Cockcroft DW, Killian DN, Mellon JJA, Hargreave FE. Bronchial reactivity to histamine: A method and a survey. Clin Allergy 1977;7:235-43.

$11 \mathrm{Nie} \mathrm{NH}$, Hull $\mathrm{CH}$, Steinbrenner K, Bent DH. SSPS, Statistical package for the social sciences. New York: McGraw Hill, 1975.

12 Breslow NE, Day NE. Statistical methods in cancer research. Vol 1: The analysis of case-control studies. Lyon: International Agency for Research in Cancer, 1980. (IARC publication 32.)

13 Miettinen OS. Simple interval estimation of risk ratio. $\mathrm{Am}$ Epidemiol 1974;100:515-6.

14 Mantel N, Haenszel W. Statistical aspects of the analysis of data from retrospective studies of disease. J Natl Cancer Inst 1959;22:719-48.

15 Miller MR, Pincock AP. Predicted values: how should we use them (editorial). Thorax 1988;43:265-7.

16 Haglind P, Rylander R. Occupational exposure and lung function measurements among workers in swine confinement buildings. J Occup Med 1987;29:904-7.

17 Heller RF, Hayward DM, Farebrother MTB. Lung function of farmers in England and Wales. Thorax 1986; 41:117-21.

18 Report of the Surgeon General. The health consequences of smoking: chronic obstructive lung disease. Rockville, Maryland: US Department of Health and Human Services Office on Smoking and Health, 1984.

19 Kauffman F, Drouet D, Lellouch L, Brille D. Occupational exposure and 12-year spirometric changes among Paris area workers. Br J Ind Med 1982;39:221-32.

20 doPico GA, Reddan W, Tsiatis A, Peters ME, Rankin J. Epidemiological study of clinical and physiological parameters in grain handlers of Northern United States. Am Rev Respir Dis 1984;130:759-65.

21 Donham KJ, Zavala DC, Merchant J. Acute effects of the work environment on pulmonary functions of swine confinement workers. Am J Ind Med 1984;5:367-75.

22 doPico GA, Reddan W, Anderson S, Flahert D, Smalley A. Acute effects of grain dust exposure during a work shift Am Rev Respir Dis 1983;128:339-404.

23 Enarson DA, Vedal S, Chan-Yeung M. Rapid decline in $\mathrm{FEV}_{1}$ in grain handlers. Am Rev Respir Dis 1985;132: 814-7.

24 Burney PGJ, Britton JR, Chinn S, et al. Descriptive epidemiology of bronchial reactivity in an adult population: results from a community study. Thorax $1987 ; 42$ 38-44.

25 Woolcock AJ, Peat KJ, Salome CM, et al. Prevalence of bronchial hyperresponsiveness and asthma in a rural adult population. Thorax 1987;42:361-8.

26 Rijcken B, Schouten JP, Weiss ST, Speizer FE, van der Lende $R$. The relationship of non specific bronchial responsiveness to respiratory symptoms in a random population sample. Am Rev Respir Dis 1987;136:62-8.

27 Enarson DA, Vedal S, Shulzer M, Dybuncio A, ChanYeung M. Asthma, asthmalike symptoms, chronic bronchitis, and the degree of bronchial hyperresponsiveness in epidemiological surveys. Am Rev Respir Dis 1987; 136:613-7.

28 Rijcken B, Schouten JP, Weiss ST, Segal M, Speizer F, van der Lende $R$. Longitudinal analysis of the relationship between bronchial hyperreactivity and pulmonary function. In: Sluiter $\mathrm{HJ}$, van der Lende $\mathrm{R}$, eds. Bronchitis $I V$. Assen: van Gorcum, 1989:94-103. 